\title{
ACRL Goals Study
}

The Association of College and Research Libraries announces the appointment of a committee to assess the goals, priorities, and structures of ACRL. The committee, chaired by Dr. Le Moyne W. Anderson, director of libraries at Colorado State University, includes James Humphry III, vice-president of H. W. Wilson Company and a former president of ACRL; Mary Louise B. Cobb, head of the Cataloging Department at the College of William and Mary; Shirley A. Edsall, assistant professor in the School of Library Science at the University of Michigan; Janice Gallinger, librarian at Plymouth (N.H.) State College; Gustave A. Harrer, director of libraries at the University of Florida; Ellsworth G. Mason, director of libraries at the University of Colorado; and Harry Robinson, Jr., director of Learning Resources Services at Alabama State University.

The charge of the committee is to describe the changing environment of research and postsecondary education, the issues and problems relating to information and library service in this environment, and ACRL's role in responding to these issues and problems. The committee is to recommend to ACRL an organizational structure for the association that would best assure this response.

The committee will meet during the ALA Annual Conference in New York City, July 7 13, 1974, to discuss progress reports, to review the history of ACRL, to evaluate the survey design and research instruments which it will use in collecting pertinent data, and to interview past and present leaders of the association.

Further information may be obtained from the chairman, Dr. Le Moyne W. Anderson, Director of Libraries, Colorado State University, Fort Collins, CO 80521.

\section{News From the Field}

\section{FELLOWS HI PS}

- Applications will be accepted this spring for more than 550 university lecturing and advanced research awards during 1975-76 in over seventy-five countries under the Senion Fulbright-Hays Program of the Council for International Exchange of Scholars (formerly the Committee on International Exchange of Persons). Specialists in library science who are U.S. citizens and have a doctorate or college teaching experience are invited to indicate their interest in an award by completing a simple registration form, available on request from the Senior Fulbright-Hays Program, 2101 Constitution Avenue, NW, Washington, DC 20418. Registrants will receive a detailed announcement of the 1975-76 program in April. July 1, 1974 is the deadline for applying for research awards and it is also the suggested date for filing for lectureships.

Each year Fulbright-Hays agencies abroad forward to the council applications of senior foreign scholars who are interested in remunerative appointments for lecturing and postdoctoral research at American colleges or universities for temporary periods. The scholars are eligible for Fulbright-Hays travel grants if arrangements are confirmed for remunerative appointments. An announcement regarding these scholars is issued in March.

The council would also be pleased to receive at any time information regarding appointments available at American educational institutions for foreign scholars for temporary periods of three months to one year. A directory of senior Fulbright-Hays foreign scholars who are in the United States this academic year is also available on request to the council. A number of these scholars would welcome invitations to give lectures or to participate in special conferences under the sponsorship of academic institutions and educational organizations.

\section{G R A N T S}

- The Akwesasne Librany Cultural CenTER has announced that it has received a $\$ 5,000$ grant from the Alcoa Foundation. The money will be used in the library and museum to build display cases and purchase materials on Mohawk culture. The Akwesasne Library Cultural Center is one of the three demonstration Indian library projects which comprise the National Indian Education Association Library Project, sponsored by the Office of Education, Division of Library Programs.

\section{MEETINGS}

April 28-May 1: Clinic on Libraty Applications of Data Processing. Conducted by the Graduate School of Library Science, University of Illinois, the theme of this eleventh 
annual clinic will be "The Application of Minicomputers to Library and Related Problems." The clinic will include a tutorial on minicomputers, demonstrations, and papers describing specific applications. Mr. F. W. Lancaster, professor of library science, is chairman of the clinic. Further information may be obtained from: Mr. Leonard E. Sigler, Clinic Supervisor OS-97, Conferences and Institutes, 116 Illini Hall, Champaign, IL 61820.

May 2-3: Managing Data Effectively will be the theme of the tenth annual National Information Retrieval Colloquium, to be held at the Holiday Inn, 18th and Market Streets, Philadelphia.

The National Information Retrieval Colloquium (NIRC) is an annual two-day conference sponsored by fourteen regional societies and organizations with interests in the information storage and retrieval sciences. The colloquium brings practitioners and academicians together to discuss and interpret new trends and technologies, current applications, and theoretical approaches to old problems.

Content of this year's colloquium will be structured into three broad areas-the management or handling of data, the technical requirements of data management, and the application of data management. Each of the three areas will be divided into sessions on the state of the art or a survey of the field, its impact, and applications or examples.

For additional information contact: Colloquium on Information Retrieval, Inc., P.O. Box 15847, Philadelphia, PA 19103.

May 3-4: Change. The New England Technical Services Librarians and New England College Librarians will sponsor a meeting at the University of Massachusetts library, Amherst, Massachusetts, on changing aspects of the library profession. For further information, contact Mrs. Pat Graves, University of Massachusetts, Amherst, MA 01002.

May 9-11: Library Orientation. The Fourth Annual Conference on Library Orientation, to be held at Eastern Michigan University, will include speakers, panels, and small group discussions.

Librarians, administrators, faculty, and students are invited. Registration will be limited to 100 persons. For further information, please write to: Hannelore Rader, Orientation Librarian, Eastern Michigan University, Ypsilanti, MI 48197.

May 13-15: Labour Relations and The Librarian. Held by the Institute of Professional Librarians of Ontario, the seminar will take place at the Wilfrid Laurier University, Waterloo, Ontario. Topics: bargaining and the pro- fessional librarian; the nature of the collective agreement; defining a bargaining unit; working conditions in a library; negotiating an agreement; and administration of the collective agreement. Total cost is $\$ 150$ (to include food and accommodation). For registration forms or further information please write to: Labour Relations Seminar, I.P.L.O. Office, 17 Inkerman Street, Toronto, Ontario M4Y IM5.

May 16-18: Management. The fifth annual seminar on "Management Concepts for Librarians," sponsored by the graduate school of Business Administration and Washington University Libraries, will be held at Bromwoods, located sixty miles southwest of the St. Louis metropolitan area.

The purpose of this seminar is to provide professional librarians managerial instruction applicable for use in their organizations, an opportunity to improve their backgrounds for work in supervisory or managerial positions, and to discuss mutual problems with colleagues. To accomplish this purpose, a basic overview of management concepts will be presented, with particular emphasis upon how those concepts are applicable to the unique problem of library organizations. In addition to the development of a general understanding of the basic functions and activities of management, the special problems of directing and motivating library personnel will be stressed. Both theoretical concepts of management and the practical applications of these concepts will be discussed. "Management Concepts for Librarians" is in general directed toward librarians at the supervisory level and to those in the middle management area, but with relevance for top library management as well.

Registration is limited to thirty-five on a firstcome, first-serve basis. The $\$ 185$ fee covers all instructional costs, Dr. Hilgert's textbook, materials, meals, and lodging while at Bromwoods. For further information please contact William H. Kurth, University Librarian, Washington University Libraries, St. Louis, MO 63130 (314-863-0100, extension 4523), or Mrs. Marilyn Pryor, The School of Continuing Education, Washington University (extension 4261).

May 17-18: Librany Technicians. The Council on Library Technical-Assistants (COLT) will hold its Third Eastern Regional Workshop at the Marriott Motor Hotel, Atlanta, Georgia. COLT is an organization concerned with the training and employment of supportative staff in libraries.

The workshop, cosponsored by the School of Library Service, Atlanta University, and the Division of Librarianship, Emory University, will focus attention on "The LTA: Catalyst for Change." Library education, personnel struc- 
ture, upward mobility, and continuing education will be among topics considered.

For registration and further information, write immediately to: Howard Blanton, Chairman, Eastern Region, COLT, Holding Technical Institute, Route 10, Box 200, Raleigh, NC 27603.

May 24-25: Midwest Academic Librarians Conference, to be held on the campus of The University of Wisconsin-Milwaukee. Details: William C. Roselle, Director, UWM Library, Milwaukee, WI 53201.

June 16-22: Administrators. An executive development program for library administrators will be offered this summer at Miami University, Oxford, Ohio, by Miami's School of Business Administration. The program is designed to assist library administrators in improving their managerial effectiveness. To accomplish this purpose the program is presented by a team of internationally known management experts-business consultants and executives and management academicians. All of these management authorities have participated in past library conferences at Miami, are familiar with library situations, and are able to relate sound management principles to the library environment. Case analysis, group discussion, problemsolving techniques, role-playing, a wide variety of audiovisual presentations-all are used to present management concepts as effectively as possible. Because of its emphasis on general management principles and techniques, the program is of value to all kinds of library administrators-public, university, special, technical, corporation, etc. Any librarians who make or influence management decisions would find the program beneficial, including library consultants and professors of library science.

The fee of $\$ 235$ includes all program expenses: tuition, instructional fees, cost of all reading materials and other handouts, personalized notebooks, plus room and board (including three banquets). Anyone interested in attending should write the program director, Dr. Robert H. Myers, School of Business Administration, Miami University, Oxford, $\mathrm{OH}$ 45056 , requesting a brochure and application form.

July 4-6: Juvenilia as a Scholarly ReSOURCE. A preconference sponsored by the National Planning of Special Collections Committee, Children's Services Division, American Library Association, will be held prior to the 1974 ALA Annual Conference in New York.

This symposium, to be held at Fairleigh Dickinson University, Madison, New Jersey, will consider such themes as: forms of juvenilia being utilized in research now; forms neglected by research collections; prototypes of collecting programs on state, regional, national and international levels in public, academic, special, and national libraries. Speakers will include researchers, curators, teachers, librarians, from institutions abroad as well as from this country.

Registration will be limited to 200 , and will close May 15, 1974. Application blanks will be available from the Children's Services Division, American Library Association, 50 E. Huron St., Chicago, IL 60611, after February 15, 1974. Registration fees, including room and meals, are $\$ 75$ for ALA members; $\$ 85$ for nonmembers. Special registration fees, without room and meals, are $\$ 45$ for ALA members; $\$ 50$ for nonmembers. Accommodations will be in Dorm Village with meals at the Student Center.

July 5-6: Serials Workshop. The Serials Section of RTSD and the Library of Congress are sponsoring two workshops on serials procedures at the Library of Congress in Washington, D.C. The workshops are intended primarily for serials librarians involved in daily serials processing and are designed to acquaint the serials librarian with the processing activities, with an emphasis on cataloging, of the Serial Record Division of the Library of Congress. The first workshop on Friday-Saturday, 5-6 July 1974, is intended for librarians who reside outside of the metropolitan Washington, D.C. area and is scheduled immediately preceding the Annual Conference of the American Library Association in New York City. The second workshop on Tuesday-Wednesday, 1-2 October 1974, will be a repeat of the first workshop and is intended for those librarians in the Washington, D.C. area.

Because of space limitations, preference will be given to those applications bearing the earliest postmark. Preregistration (by I June for the July workshop and by 1 September for the October workshop) and confirmation are required. Application forms may be obtained from Herbert Linville, Chairperson, Serials Section, RTSD, University of California Library, Santa Barbara, CA 93106 (telephone 805-961-2854), or Joseph Howard, Chief, Serial Record Division, Library of Congress, Washington, DC 20540 (telephone 202-4265302).

July 7-8: Census Data. The Education and Behavioral Science Section will sponsor the Clearinghouse and Laboratory for Census Data (operated by Data Use and Access Laboratories of Rosslyn, Virginia) in a day and a half seminar/workshop on access and use of 1970 Census of Population and Housing data during the 1974 ALA Annual Conference in New York. For further information see the January News. 
July 7-13: Library Automatron, A workshop on the latest techniques in library automation, sponsored by Richard Abel \& Company, will precede the 1974 American Library Association conference in New York City.

Persons interested in further information or in participating in the workshop should contact the Abel Workshop Director at this address: Abel Workshop Director, Richard Abel \& Company, Inc., P.O. Box 4245, Portland, OR 97208. See the March News for more information.

July 28-Aug. 9: Administratons. The College of Library and Information Services, University of Maryland, is planning the eighth annual Library Administrators Development Program. Dr. John Rizzo, professor of management at Western Michigan University, will serve as the director. Participants will include senior administrative personnel of large library systems-public, research, academic, special, governmental, and school-from the United States and Canada. Those interested in further information are invited to address inquiries to Mrs. Effie T. Knight, Administrative Assistant, Library Administrators Development Program, College of Library and Information Services, University of Maryland, College Park, MD 20742. See the January News for further information.

August 5-6: Media. "Differentiating the Media: A Focus on Library Selection and Use of Communication Content" will be the topic of the Thirty-Seventh Annual Conference of the

\section{ATTENTION, LPSS MEMBERS}

What do you, as a member of the Law and Political Science Section of ACRL, see as the goals, objectives and functions of LPSS? Social? Meeting librarians with similar concerns? Distributing information concerning government documents, bibliographic services, education, and the like?

Can you help achieve these goals? Will you work on committees? Prepare bibliographies? Participate in programs? Serve as an officer?

The officers of LPSS need your input! Please send your thoughts about these (and any other) questions to: Ms. Joan L. Chambers, Government Publications Librarian, University of Nevada, Reno, NV 89507. (See you at the membership meeting in New York-July 9 from 4:30 to $6: 00 \mathrm{p} . \mathrm{m}$.)
University of Chicago Graduate Library School. The aim of the conference is to go beyond the current pro and con arguments about the "new media" and to stress, instead, the characteristics of each medium which influence its effectiveness as a carrier of different kinds of communication to serve different kinds of needs for different kinds of audiences. Through this kind of analysis, the conference will attempt to identify the principles on which to base the evaluation of each medium for its most effective contribution to better library service.

Among the speakers from the media fields will be Ron Powers, Pulitzer Prize-winning television and radio columnist, the Chicago SunTimes; Professor Donald R. Gordon, faculty of arts at the University of Waterloo and author of The New Literacy; and Virginia Wright Wexman, associate producer in the Radio and Television Office, University of Chicago, and extension lecturer on Film and Literature. Librarian speakers will include Wesley Doak, audio-visual consultant, California State Library; and Frances Henne, professor, Columbia University School of Library Service.

The conference will be held at the Center for Continuing Education on the University of Chicago campus. For further details about registration, housing, etc., write to either of the conference directors, Lester Asheim or Sara I. Fenwick, Graduate Library School, University of Chicago, 1100 East 57th Street, Chicago, IL 60637.

\section{MIS CELLANY}

- The American Association of Community and Junion Colleges maintains a Career Staffing Center for its member institutions and those individuals who would like to be considered for staff positions at more than $900 \mathrm{mem}$ ber colleges. Write for details to AACJC Career Staffing Center, P.O. Box 298, Alexandria, VA 22314.

- McKissick Memorial Library, University of South Carolina, has put into operation the first light scanning device in the nation to check out a book with the flick of the wrist. The scanners are connected to a minicomputer and record the shaded code number of a book in the computer. Each student has a library code on the back of his indentification card which is recorded in the computer after the book code. Thus with two sweeps of the light scanner a book that is being checked out and its borrower are recorded in the USC computer which further takes care of such details as overdue statements and statistics as to how many books are checked out at one time and what category of people have what checked out. 
The system was developed at USC by the library staff in cooperation with the university's Department of Mathematics and Computer Science and the USC Computer Center.

- The Women's History Library's Summer Volunteer Intern Program is open to all individuals interested in developing women's resource collections. The deadline for summer program (June-September) applications is May 1. Unfortunately, no stipends are available. For information write: Linda Schuck, Women's History Library, 2325 Oak, Berkeley, CA 94708.

- A 16-months' multinational Course on National Library and Documentation Systems for Development will be offered by the Organization of American States at the Graduate School of Librarianship of the University of Denver, Colorado, beginning June 17, 1974. The objective of the course is to train national and regional teams of experts in the techniques and technology of information management, so that they may be capable of developing the various aspects of library and documentation systems which form the library infrastructure necessary for the organization and transmission of information to meet the demands and needs of national users and the expressed interests of the countries.

Through the training of the specialists in teams, the OAS plans to promote the acceptance and application of universal library standards so as to make compatible the different information systems being developed in Latin America, especially in regard to automated bibliography and compatibility with the MARC format of the Library of Congress. Furthermore, the specialists will be trained to make use of electronic technology as applied to documentation, as well as of the bibliographic data banks developed in other parts of the world, in order to solve the problems of information services in the countries of Latin America. It is expected that they will be capable of drafting programs and developing projects to create similar capacities in the region, not only in the fields of science and technology, but in the social sciences, economics, and the humanities as well, through national and regional systems and subsystems.

Further information on the course may be obtained from Mrs. Marietta Daniels Shepard, Chief of the Library and Archives Development Program, Organization of American States, Washington, DC 20006. For information on acceptance of candidates by the University of Denver Graduate School of Librarianship, please refer to Mrs. Margaret Knox Goggin, Dean, University Park, Denver, CO 80210.

- Three graduate programs of library edu- cation have been officially accredited by the American Library Association under Standards for Accreditation, 1972, according to an announcement issued by the Commitree on AcCreditation at the ALA Midwinter Meeting in Chicago. The programs, which are the first to be accredited under the new standards adopted by the ALA Council in 1972, are offered by the Graduate Library School, University of Arizona (Donald C. Dickinson, Director); the Graduate School of Library Science, Louisiana State University (Donald D. Foos, Dean); and the Graduate School of Library and Information Science, University of Tennessee (Knoxville) (Gary R. Purcell, Director).

\section{P U B L I C A T I O N S}

- The Library Associates is publishing a series of Reference Book Guides. Each guide, on a separate piece of five-by-eight-inch stock in a standard format, is a short, graphic key to a particular reference book. Subscribers to the service can insert the $R B G$ anywhere in the book, tape is on or inside the front cover, or even tack it on the desk or wall area adjacent to the reference bookshelf.

Some typical titles for which $R B G$ s are published are: Readers' Guide to Periodical Literature, Statistical Abstracts of the U.S., P.A.I.S., Handbook of Chemistry and Physics, Writer's Market, and the MLA Bibliography. Reference Book Guides are available by two subscription plans: $\$ 48$ per year for 120 different guides; $\$ 25$ for any 40 per year. The guides may also be purchased individually, and bulk-rate discounts are generous.

To place an order or for more information and a sample, write: Reference Book Guides, The Library Associates, P.O. Box 3411, Boulder, CO 80303.

- A new series of the Women's History Library's Herstory Microfilms are now available. The forty reel double set of $35 \mathrm{~mm}$ microfilms includes journals, newspapers, and newsletters from women's organizations.

One set, the Herstory 1 Update, covers the period October 1, 1971 to June 30, 1973. The second set, Herstory 2, covers the same period and includes titles which began after October 1, 1971. Herstory 1, available from Bell and Howell, is now used in over 100 libraries around the country.

The Herstory Collection of microfilms is an invaluable addition to any library or women's resource collection. Herstory 1 Update and Herstory 2 can be ordered for $\$ 880$ directly from the Women's History Research Center, 2325 Oak Street, Berkeley, CA 94708.

- A 23-page authors and titles index to the 


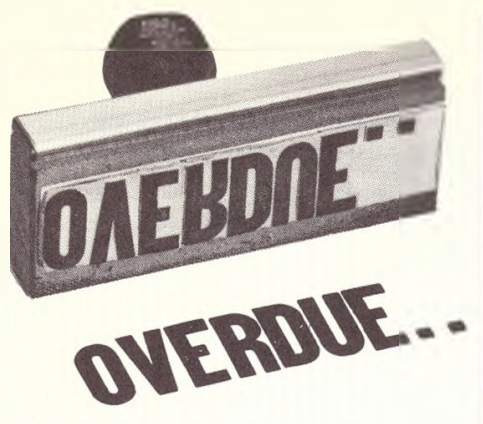

\section{Combined Indexes $t$ Library of Congre Classification Scher} First Edition 1974

For Years ... library authorities have recognized and encouraged the growing us of Congress Classification system in various types and sizes of libraries.

Also for Years .... they have expressed the need for combined indexes linking classification schedules-indexes which would bring together all the terms that relate to PERSON, PLACE or SUBJECT in the system. HERE THEY ARE!

\section{PERSONS}

d. Bound, postpaid in North America $\$ 138.00$

• ․ Set II. BIOGRAPHICAL SUBJECT TO THE LIBRARY OF CONGRESS CLASSIFICATION SCHEDULES, 1974. 3 Volumes, Cloth Bound, postpaid in North America $\$ 195.00$

\section{Id.}

Set III. CLASSIFIED INDEX TO PERSONS IN THE LIBRARY OF CONGRESS CLASSIFICATION SCHEDULES, 1974. 3

Volumes, Cloth Bound, postpaid in North America $\$ 195.00$

\section{PLACES}

(ब)

Set IV. GEOGRAPHICAL LIBRARY OF CONGRESS CLASSIFI 1974. 1 Volume, Cloth Bound, post

\section{SUBJECTS}

(6) C. C. Set V. SUBJECT THE LIBRARY OF CONGRESS CLA: ULES, 1974, 6 Volumes, Cloth Bour America



The complete 15 volume set of COMBINED IND LIBRARY OF CONGRESS CLASSIFICATION FIRST EDITION, 1974. Cloth Bound, postp America 


\section{to the}

\section{ress}

edules

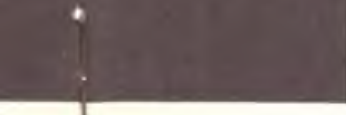

ng use of the Library

king all 31 separate

e to every

ICAL NAME INDEX TO THE ASSIFICATION SCHEDULES, postpaid in North America

$\$ 68.50$

JECT KEYWORD INDEX TO CLASSIFICATION SCHED. Bound, postpaid in North $\$ 395.00$

\section{INDEXES TO THE} ION SCHEDULES, ostppid in North $\$ 985.00$
Now for the first time catalogers, reference librarians and researchers need look in only one place for LC class numbers and still be confident that they covered all aspects of every subject cited in the schedules.

\section{In Reference Work}

The acquisition of these new Combined Indexes will enhance the accessibility - and hence the overall reference value-of all types of library collections in which the LC Classification system is being used or contemplated.

The single-alphabet arrangement of the personal name indexes brings together in one place all numbers assigned to persons prominent in several fields, as well as to authors who have wrilten in more than one language. Entries show class numbers with the proper form of each name as well as cross references and pseudonyms.

In the case of geographical names, the bringing together of class numbers for all the various terms in the system which might apply to any given country or area, marks a major reference achievement in itself.

Meanwhile, the specificity of the hundreds of thousands of keywords sorted alphabetically in the general Subject Keyword Index offers researchers a means of identifying subject-oriented classes with in-depth accuracy not previously possible.

The "classified" indexes to authors and other persons will also prove to be major reference tools, as they will bring together the numbers of individuals in various categories and time-periods for use in various types of comparative studies.

\section{In Cataloging}

The personal name indexes will be invaluable as the first sources to consult when cataloging a literary work or biography. In the larger libraries they will replace many lengthy searches in the National Union Catalog. In smaller libraries without access to the NUC, the combined indexes will enable catalogers to find and use correct classifications immediately, rather than having to contact other libraries or resort to creating their own class numbers.

The massive single-alphabet Keyword Subject Index will aiso prove to be a major cataloging tool for both large and small libraries. In the larger systems where catalogers are specialists and hence familiar with their assigned portions of the schedules, the major advantages of the combined index set lie in its convenient one-step format and the added dimension of its in-depth keyboard subject indexing. For new catalogers or lone catelogers in small libraries, for whom identifying correct schedules is a time-consuming problem in itself, the combined indexes offer an immediate additional advantage.






\section{THE Series Catalog.}

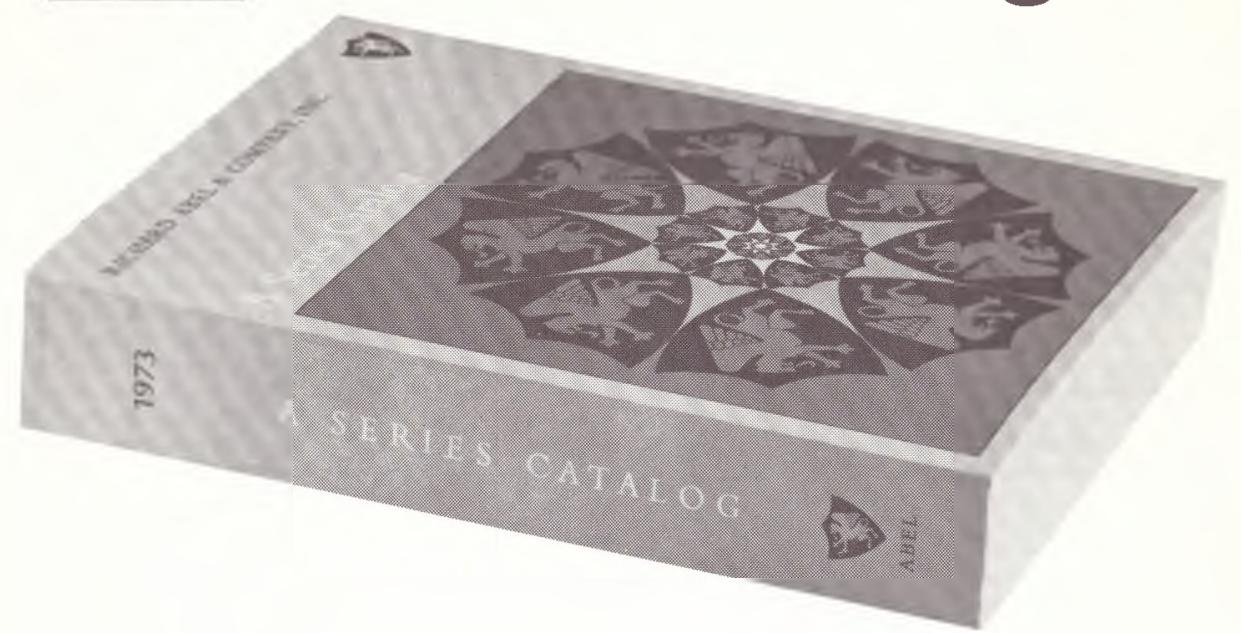

\section{Yours for the asking.}

Richard Abel \& Company's Series Catalog is a unique new reference tool, designed to help librarians verify and order publications in series. It's been called "The most comprehensive listing of series for which any book dealer routinely accepts standing orders." And immediate, fully-automated Standing Order service is available for every series listed in the Catalog (and many more). Your 890-page Series Catalog features:

\section{4,000 Author/Title Entries--28,000 series} titles, plus 6,000 essential cross-references.

Classed Subject Index-44,000 entries, under 145 different subject headings.

\section{Price, Frequency and Volume Count-} provided to help you budget.

Comprehensive Coverage-of series, sets, editions, non-subscription serials, journal supplements, fascicles, etc.

\section{Bibliographic Integrity-determined and} verified by professional librarians and bibliographers.

Your Series Catalog is the key to the surest, most efficient Standing Order service available today. You can verify the existence of a series and its correct entry, and initiate your standing order in almost no time at all. Then you can count on fast Abel service. You can order back volumes with the aid of our history file, and count on receiving future volumes as soon as they're published

THE Series Catalog sells for $\$ 17.50$. Send us your order today, or find out how you will get your copy tree by calling this toll-free number: 800-547-3551.

THE SERIES CATALOG
$\square$ Tell me more about your Standing Order
services.
$\square$ Tell me how I can get THE Series Catalog
free.
$\square$ Send me THE Series Catalog.
$\square$ My check is enclosed.
$\square$ Please bill me later.
Name__
Library
Address
City/State/Zip_

Richard Abel \& Company, Inc.

P.O. Box 4245/Portland, Oregon 97208 (503) 645-3511/Telex 36-0458

OFFICES IN: Mill Valley, $\mathrm{Ca}$ • Los Angeles • Denver • Dallas Kansas City, Mo. - Zion, III. - Marion, Oh. - Nashville, Tn. Atlanta, Ga. Washington, D. C. Blackwood, N.J. Newton Centre, Ma. - Toronto • London - Amsterdam - Melbourne Sao Paulo. 
volumes published through 1973 of Flügge Handbuch der Physik has been compiled in the library at M.I.T. Lincoln Laboratory. Anyone needing this may have a copy by sending a simple request, together with $30 \notin$ in postage stamps and a self-addressed mailing sticker, to Loyd Rathbun, M.I.T. Lincoln Laboratory, Lexington, MA 02173.

- Compiled in the last months of 1973, Social Work Reference Aids is the latest in a series of bibliographic guides published by the John P. Robarts Research Library. The bibliography aims to simplify study, practice, and research in the field by providing an introduction to the most authoritative up-to-date sources of information in social work and related subjects. Approximately 250 annotated entries cover such topics as aging, alcohol and drug abuse, the family, poverty, and urban and community development. An author and title index is included. Copies can be ordered from the Reference Department, John P. Robarts Research Library, University of Toronto, Toronto, Ontario, Canada M5S 1A5, for $\$ 5$.

- Library Applications of Data Processing, proceedings of an Allerton Park Institute April 29-May 2, 1973, has been published by the Graduate School of Library Science, University of Illinois at Urbana-Champaign.

The tenth annual clinic on this topic, it was devoted to the subject of cooperation between libraries in data processing activities. Speakers at the clinic discussed the feasibility and economics of such cooperation. Major emphasis was placed on data processing within library networks and in cooperative processing centers.

Single copies are available from the Illini Union Bookstore, Urbana, IL 61801. The price is $\$ 6$ a copy.

- Alaska Place Names, an update to Orth's Dictionary of Alaska Place Names (USGS, 1968; rev. 1971), has been published by the University of Alaska. It is 34 pages, and costs \$2. Inquiries should be directed to Betty Arnold, Adm. Sec., Elmer E. Rasmuson Library, University of Alaska, Fairbanks, AK 99701.

- The Stanford University Libraries has published a second, revised edition of $\boldsymbol{A}$ Survey of Library Materials Expenditures at Stanford University Libraries, prepared by Fred Lyndon of the Acquisitions Department. This new edition contains more up-to-date information which will be useful to libraries faced with both increasing costs of obtaining scholarly publications and the rapidly increasing number of publications needed for scholarly research. Because of the continued importance and need for this type of study, the Stanford University Libraries is making it available to other libraries for $\$ 6$. It can be ordered from the Financial Office, Stanford University Libraries, Stanford, CA 94305 .

- The Special Cataloging Project at the Library of the School of Theology at Claremont, California, has analyzed Corpus Scriptorum Christianorum Orientalium through volume 333.

It can provide copies of the main entries of these analytics at 20 each. These give all tracings, including series entries which include volume numbers for the series and the subseries.

These volume numbers are often not given on early Library of Congress copy. These main entries also update the Library of Congress open entries. Many of the STC entries reflect the fact that they have been cataloged from "réimpression anastatique" copies published by L. Durbeck in Louvain.

Please address orders to: Elizabeth $\mathbf{H}$. Weeks, Head, Special Cataloging Project, The Library, School of Theology at Claremont, 1325 N. College, Claremont, CA 91711.

Please prepay, making checks payable to: The Library, School of Theology at Claremont.

- Under the sponsorship of the Bibliographical Society of the University of Virginia, the index to printers, publishers, and booksellers in the second edition of Donald Wing's ShortTitle Catalogue is being prepared by Clinton Sisson, research librarian, Alderman Library, University of Virginia, Charlottesville, VA 22901. Inquiries and other correspondence about the project, which is now in progress, may be sent to Mr. Sisson at the library.

\section{SIBERIAN FOLKLORE}

Dr. Cyril Jauksch-Orlovski, associate professor at the Department de langues et linguistique, Faculte des lettres, Universite Laval, Quebec 10, Canada, is preparing an analytical and chronological bibliography of Russian folklore in Siberia (1581 to the present) which will contain about two thousand Russian titles translated into English and French. The Academy of Sciences of the Union of Soviet Socialist Republics has appointed Professor L. E. Eliasov and M. J. Mele as consultants for this work. Persons interested in this field are invited to contact Dr. C. Jauksch-Orlovski at the above address. 
LIBRARIES said: "An important contribution." - CHOICE said: "Recommended for purchase."

\section{OF}

\section{SPECIAL LIBRARIES}

\section{AND INFORMATION CENTERS}

\section{Edited by MARGARET LABASH YOUNG, HAROLD C. YOUNG, and ANTHONY T. KRUZAS}

Salient features of the new, 3rd edition include - Over 25,000 changes in addresses, phone numbers, sponsors, staff, collection statistics, holdings, services, pub. lications, etc. - Phone numbers now include area codes and extensions, when available - All previous entries completely revised 4,000 brand-new entries - 14,000 entries altogether - Entries cover 17 helpful points including: Name, Address, and Phone Number ... Sponsoring Organization ... Informational Specialty ... Names of Person in Charge and Other Staff Members ... Holdings (Number of Books, Periodicals, Maps, Manuscripts, Filmstrips, Specimens, etc.) . . . Special Collections ... Subscriptions ... Publications

Catalogs and Indexes... Services (loans, copying, etc.). - Detailed Subject Index identifies sources of knowledge on more than 2,000 topics. Entries arranged alphabetically by names of sponsoring organizations - Over 5,000 cross references
$-1232-($ Soc Sci)

GUREAU OF SOCIAL SCIENCE RESEARCH - UIRRARY

1990 M S1., N.W, Phone: (202) 223-4300

Washington, DC 20036

F. Glorio bock, Librarion

Subjects: Behovioral ucience; social seience methadoloyr

Holdings: 3000 books: 600 bound periodical volumes.

Subscriptions: 125 journols and other verials.

Services: Interlibrory loons; eopying: library is open to qualified persont by sppointment only.

Publications: Quarterly Newsletter.

Wurgest-Corpenter Library

SES: COLUMBA UNIVERSITY - BURGESS-CARPENIER LIBRARY

- 1233 - (Sei-Tech)

BURGESS INDUUSTRIES ENVIRONMENTAL GROUP -

ENOINEERING LIBRARY

$\begin{array}{ll}\text { A101 Carpenter Freewry } & \text { Phone: }(214) 631-1410 \\ \text { Dallos, TX } 75247 & \text { Founded: } 1930\end{array}$

E.J. Horter: Stoff: Prof 1; Other 1

Ohief RBD Engineer

Subjects: Acoustics; silencers; mechanical separators, llvid mechanics; thermedynamia; noise pollution; air pollution.

Spocial Collections: Acourtical Society journaly from first volume to present.

Holdings: 200 books 100 bound periodical volumes; 800 reports (catologed).

Services: Librory is not open to outside users.

Stall. M. D. Finley, Libraion-Secretary.

\section{NOW IN PRESS}

\section{FOR JUNE PUBLICATION}

The first new edition since 1968 .

in a handy 3 -volume arrangement . . .

Vol. 1: Special Libraries and Information Centers in the United States and Canada, 3rd ed., 1,428 pages. 81/2" $x 11^{\prime \prime} . \$ 48$.

Vol. 2: Geographic-Personnel Index. 600 pages. $81 / 2$ " $\times 11^{\prime \prime} . \$ 28$.

Vol. 3: New Special Libraries. Inter-edition supplement service. Subscription, four issues with binder for new subscribers. $\$ 42$.

Order now .... and add 14,000 "branches" to your library. Make it a STANDING ORDER and receive future editions of this valuable reference tool automatically.

\section{Gale Research Company} Book Tower/Detroit, Michigan 48226
Burlew Medical Library

SEE: SAINT JOSEPH HOSPITAL - BURLEW MEDICAL LIBRARY

$-1234-($ Mist)

QURLINGTON COUNTY HISTORICAL SOCIETY -

DELIA BIDDLE PUGH LIBRARY

Burlington, NJ 08016

Phone: $(609) 386-4773$

Beotrice Bnnswick, Curgtos

Founded: 1915

Stoff: Prol 2

Subjech: History of Burlington and New Jersey, expecially Southem New Jerney; entiques; colonial arh and crafh.

Special Collections: James Fenimore Cooper worka and aitiques; geneology of Burlington County.

Holdings: 1500 books; 300 bound periodical volumes; deeds; phologrophs; slides; elippings.

Services: Librory open to public by appointment.

Staff Ruth Bump, Trustee in charge of Library.

\section{SAMPLE ENTRIES REDUCED}

